\title{
Work Ability and Psychosocial Factors among Hairdressers Workers, Rio de Janeiro, Brazil
}

\author{
CAPACIDAD PARA EL TRABAJO Y LOS FACTORES PSICOSOCIALES EN TRABAJADORES DE PELUQUERÍAS, RÍO \\ DE JANEIRO, BRASIL
}

Aldo Pacheco Ferreira

Docente e Investigador, Escuela Nacional de Salud Pública Sergio Arouca, Centro de Estudios de la Salud del Trabajador y Ecologia Humana, Rio de Janeiro, Brasil.

\section{ABSTRACT}

This study came up with the main objective to inspect psychosocial health and wellbeing factors that affect the work ability of hairdresser. A cross-sectional and descriptive study was carried out in which 106 hairdressers workers were surveyed. To this end, the Work Ability Index (WAI) and Copenhagen Psychosocial Questionnaire (COPSOQ) questionnaires were administered. The results demonstrate that the sociodemographic variables gender, age and educational attainment are influenced by psychosocial health factors. The average WAI score among workers was 40,7 points $(S D=7,2)$, ranging from 24 to 49 points and the prevalence of good capacity for work was $77,36 \%$. Regarding to the symptoms of stress were obtained in difficulty to think clearly $(16,03 \%)$, pain or problems in the stomach $(13,21 \%)$, tension in various muscles $(15,1 \%)$, difficulty making decisions $(13,21 \%)$, lack of initiative $(8,49 \%)$ and tightness or chest pain $(9,43 \%)$ in respondents. The administrators of beauty salons should be aware of the results obtained with this category of workers so little studied (but very prominent today) to pore in creating an environment conducive to maintaining the work capacity and well-being of hairdressers, mitigating the problems encountered with this study.

Key words: OCCUPATIONAL HEALTH, WORK CAPACITY EVALUATION, PSYCHOSOCIAL IMPACT, WORKING CONDITIONS

\section{RESUMEN}

Este estudio tiene el objetivo principal de examinar los factores de salud y bienestar psicosociales que afectan a la capacidad de trabajo en peluqueros. Se aplicó los cuestionarios (Índice de Capacidad para el Trabajo - ICT y Psicosocial de Copenhague - COPSOQ) a 106 peluqueros. Los resultados demuestran que las variables sociodemográficas sexo, edad y nivel de estudios se ven influidas por factores psicosociales relacionados con la salud. La puntuación media de lo ICT entre los trabajadores fue de 40,7 puntos ( $D E=7.2$ ), que van desde 24 hasta 49 puntos y la prevalencia de la buena capacidad de trabajo fue $77,36 \%$. Con respecto a los síntomas de estrés se obtuvieron en dificultad para pensar con claridad $(16,03 \%)$, dolor o problemas en el estómago $(13,21 \%)$, la tensión en varios músculos $(15,1 \%)$, dificultad para tomar decisiones $(13,21 \%)$, la falta de iniciativa $(8,49 \%)$ y la opresión o dolor en el pecho $(9,43 \%)$ en los encuestados. Los administradores de salones de belleza deben ser conscientes de los resultados obtenidos con esta categoría tan poco estudiada para la creación de un entorno propicio para el mantenimiento de la capacidad de trabajo y el bienestar, permitiendo así a mitigar los problemas encontrados con este estudio.

(Pacheco A, 2015. Capacidad para el Trabajo y los Factores Psicosociales en Trabajadores de Peluquerías, Río de Janeiro, Brasil. Cienc Trab. EneAbr; 17 [52]: 83-88).

Palabras clave: SALUD LABORAL, EVALUACIÓN DE CAPACIDAD DE TRABAJO, IMPACTO PSICOSOCIAL, CONDICIONES DE TRABAJO

\section{INTRODUCTION}

Throughout times there have been changes, which require restructuring work processes, such as the introduction of new technologies in order to improve production quality and quantity; more demands on workers, qualifications and working

\author{
Correspondencia / Correspondence: \\ Aldo Pacheco Ferreira \\ Escuela Nacional de Salud Pública Sergio Arouca, Centro de Estudios \\ de la Salud del Trabajador y Ecología Humana \\ Rua Leopoldo Bulhões, 1480, 21041-210, \\ Manguinhos, Rio de Janeiro, Brasil \\ Tel.: +55 2125982814 \\ e-mail: aldopachecoferreira@gmail.com \\ Recibido: 26 Enero 2015 / Aceptado: 12 de Febrero 2015
}

hours. These and / or other factors lead to adverse effects, including psychosocial factors at work, stress, fatigue, etc. ${ }^{1}$ The wear deriving from demands of work can be linked to chronic and acute physiological responses, psychological reactions and behavioral changes, with the possibility of decreased functional capacity and ability to work and triggering work-related diseases. ${ }^{2,3}$ On the other hand, requirements that are characterized as positive can promote and protect the health, work capacity and functional capacity, whatever the age of the worker. ${ }^{4}$

If, on one hand, the work presents an essential role in personal development and for social life $\mathrm{e}^{5}$, on the other shows becoming more individualized, brash and demanding the psychic level may even lead to imbalance of the mental health of workers. ${ }^{6}$ In other words, the work can be painful when its context creates discomfort, effort and suffering too much and where, in addition, the worker has not any control over it. $^{7}$ In fact, there are several studies showing a strong association between the requirements psychological work and the occurrence of minor mental disorders. ${ }^{8}$ 
The work ability obtains guidance of numerous issues, including social and demographic characteristics, the lifestyle, the health state and aspects associated to work. ${ }^{9}$ The interest in developing this study, with workers belonging to hairdressing, relates to the fact that among the various professional classes, this stand out as being one of the sectors most affected by psychosocial factors, including the stress labor. ${ }^{10,11}$ Hairdressing is a professional category working with human hair, making several changes at the same as cutting or colouring, with significant participation of women in beauty salons. Their actions, with the application of products containing chemical formulations, expose them, creating potential work stress. ${ }^{12,13}$

The World Health Organisation has estimated 217 million cases related occupational diseases. ${ }^{14}$ Notwithstanding, stressful events such as poor working conditions, poor organization, lack of control over work tasks and conflicting labour relations, longterm, cause organic changes that can, among other consequences, compromising worker performance. ${ }^{13}$ The posture, physical and intellectual effort, the number of working hours, also considering the shifts, worker motivation and interpersonal relations have been reported in several studies as being some of the most important factors to consider in occupational health. ${ }^{15,16}$ Also the degree of participation in the labour, environment and organization of work, the rhythm and its intensity and autonomy are among the many factors that affect the health of less obvious form of workers. ${ }^{7,17-19}$

Thus, the Occupational Health focuses on the promotion and maintenance of physical and psychosocial health of those in your workplace, taking into account the various factors that influence the labour quality, health and wellness. In this context, determining work ability has increasingly gained relevance and has been recently used as an important tool to predict workers' capabilities to perform their tasks in the future. ${ }^{20}$ In addition, maintaining good work ability has become increasingly important in prolonging working life and reducing losses from the workforce. ${ }^{21}$

\section{MATERIALS AND METHODS}

\section{Procedures}

A cross-sectional and descriptive study was carried out in hairdressers workers were surveyed.

The methodology encompassed the work ability analysis using the Work Ability Index ${ }^{9}$ and the characterization of the psychosocial factors using the Copenhagen Psychosocial Questionnaire. ${ }^{22}$ The WAY and COPSOQ were self-administrated during 2013-2014 to hairdressers.

A total of 106 females employed in 30 beauty institutes on the district of Jacarepaguá, were included in this study (Figure 1). For the data collection there was application of face-to-face questionnaires, which consists of a self-completion questionnaire. All subjects were aware of the objectives of the study and gave informed consent to participate. Exclusion criteria included being on leave due to disease, having participated in the pretest, being on vacation during data collection, and having answered incompletely to any of the questions posed. This led to the exclusion of $6,6 \%$ of all workers. This study received approval from the Bioethics Committee (0054.0.031.000-06) (Sergio Arouca National School of Public Health/Ensp/Fiocruz).

The interviews had previously done field surveys and had expe-
Figure 1.

Hairdresser cohort by age group.

Number of study participants by age group (total $=106$ )

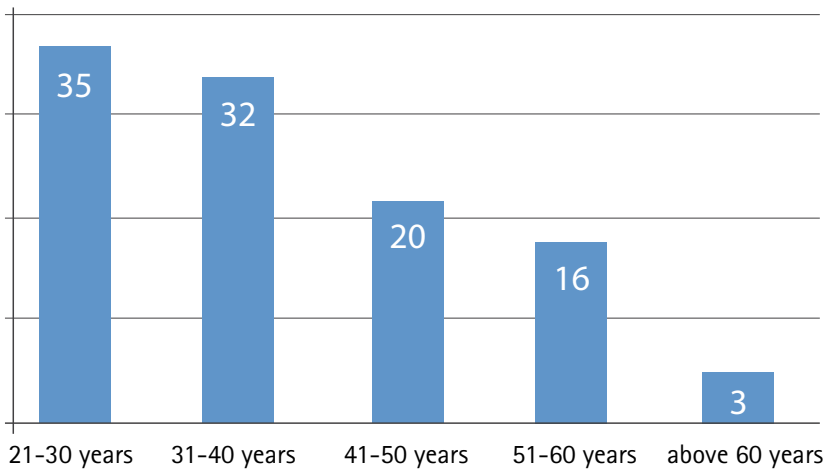

rience of face-to-face interviews were done by 3 trained interviewers, all of whom had graduate education. During preliminary meeting for the research, the participants had the presentation of research proposal, information about the procedures involved and the invitation to participate. Participation in the study was formalized through the signing of the consent form. The interviews were done by 3 trained interviewers, wholly of who had graduate schooling. A pilot study was undertaken during 2012 to check suitability of the questions for the study population.

\section{Study site}

Jacarepaguá with a land area of 29,27 square miles $\left(75,8 \mathrm{~km}^{2}\right)$ is the 4th largest neighbourhood in the city of Rio de Janeiro, Brazil. In 2010 , it had a population of 100,822 , making it the 9th most populous neighbourhood in the city. ${ }^{23}$ The name comes from the indigenous name of the location, shallow pond of alligators, by the time of the Portuguese invasion. Is located in the West Zone of Rio in the Baixada de Jacarepaguá, between Maciço da Tijuca

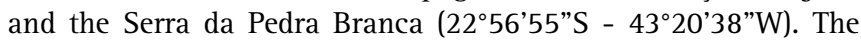
upper middle class Barra da Tijuca separates the suburb from the sea. Is divided into the following sub-areas: Anil, Curicica, Cidade de Deus, Freguesia, Gardênia Azul, Pechincha, Praça Seca, Rio das Pedras, Tanque, Taquara, and Vila Valqueire. The quarter of Freguesia, is part of the suburb Jacarepaguá in the West Zone of the city of Rio de Janeiro, Brazil. In 2010 its estimated population was 54,010 inhabitants. ${ }^{23}$ (Figure 2)

\section{Beauty institutes}

Although not officially designated, Brazilian beauty institutes are 'classified' as categories A, B and C, according to the number of employees, size of the establishment, location, type of beauty products in use and offered services. In this investigation all institutional categories of were included.

\section{Questionnaires}

COPSOQ - the Danish original study

The COPSOQ (Copenhagen Psychosocial Questionnaire) has been developed and validated by the Danish National Institute for Occupational Health in Copenhagen. ${ }^{22}$ The questionnaire was aimed to be theory-based without being based on one specific theory. Therefore, the COPSOQ is covering a broad range of aspects of currently leading concepts and theories. The following are mentioned: 1. The job characteristics model. 2. The Michigan organizational 
Figure 2.

Study area: Localization of Jacarepaguá, State of Rio de Janeiro, Brazil.

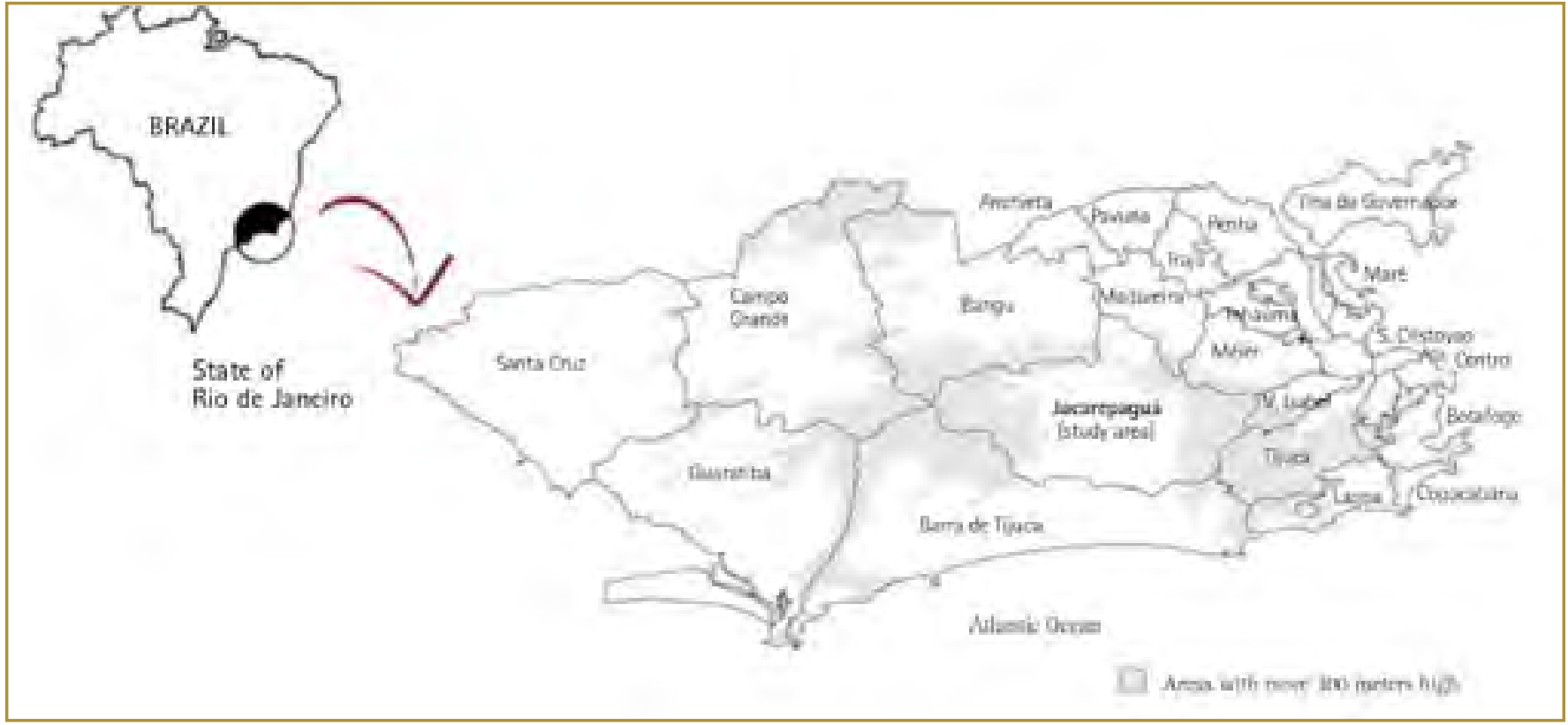

stress model. 3. The demand-control-(support) model. 4. The sociotechnical approach. 5. The action-theoretical approach. 6. The effortreward-imbalance model. 7. The vitamin model. The COPSOQ tries to deal with the broadness respectively indefiniteness of the construct psychosocial factors by applying a multidimensional approach with a very wide spectrum of ascertained aspects. ${ }^{24}$

The COPSOQ presents itself as a multidimensional instrument, a tripartite methodology. It is a powerful tool that brings together international consensus on the validity of modernity and comprehensiveness in the evaluation of many of the most relevant psychosocial dimensions inherent in the work context. ${ }^{25}$

\section{Work Ability Index}

The work ability evaluation was done through the Work Ability Index (WAI) developed by Finnish researchers and based on workers' self-perception. ${ }^{20,26,27}$ It is composed of seven aspects: 1) the person's current work capacity compared with the best of their life; 2) the work capacity compared with the work demands; 3) total number of self-perceived diseases diagnosed by the physician; 4) estimated loss of work due to illness; 5) absence from work due to illness; 6) self prognosis of work capacity; and 7) mental resources. The results can vary between a score of seven to 49 points, with a score of seven to 27 classified as the group with Low work capacity, 28 to 36 with Moderate capacity, 37 to 43 Good, and 44 to 49 with Excellent work capacity. The results can be used collectively or individually.

Achievement data on hairdressers' occupational activities The obtaining data on hairdressers' occupational activities was planned, implemented and evaluated according to the model described by Goldenhar et al. ${ }^{28}$ (Figure 3). Groups in three phases for evaluation process in occupational safety and health: development, implementation and effect evaluation. Each phase consists of five central tasks: gathering background information; developing partnership; choosing methods and design; completing development, implementation and evaluation; and reporting and disseminating the process and results. The process described encourages going a step backwards whenever the five tasks in each phase have been completed in order to evaluate and improve the development, implementation and occupational evaluation.

\section{Statistical analysis}

The statistical analyses were performed using the Origin 8.0 (OringinLab). The mean and dispersion of the data were calculated, and the results were compared to linear generalized models assuming a Gaussian distribution. To assess the independent

Figure 3.

A conceptual model for hairdressers' occupational evaluation (Goldenhar

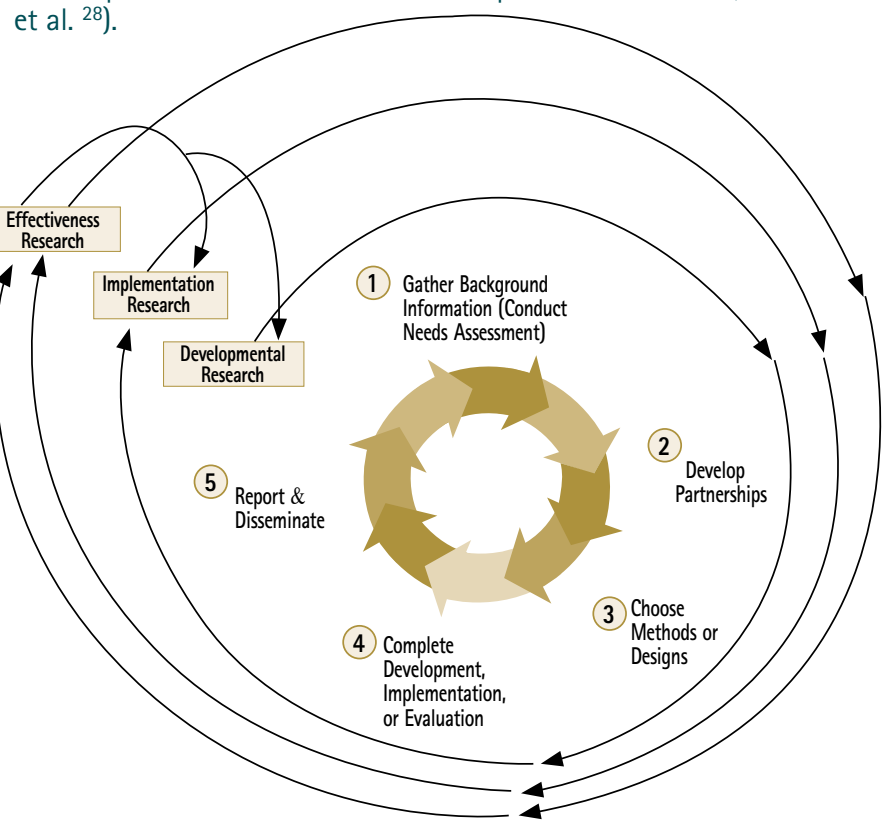


statistical relationships of all relevant variables simultaneously, a multiple regression analysis was used. The tests were interpreted using a 5\% degree of significance.

\section{RESULTS}

\section{Hairdresser Profile}

The study participants consisted of a group of 106 female hairdressers divided into the age-specific cohorts, there were 35 (21-30 years) $($ mean $=25,42 ; S D=3,13693) ; 32$ (31-40 years) $($ mean $=35,56 ; \mathrm{SD}=3,14117) ; 20$ (41-50 years) $($ mean $=44,9 ; \mathrm{SD}$ $=2,9718) ; 16$ (51-60 years) (mean= 55,62; $\mathrm{SD}=3,11716)$; and 3 (above 61 years) (mean $=63 ; \mathrm{SD}=2$ ). The majority reported living on the district of Jacarepaguá $68,9 \%(n=730$, Rio de Janeiro and $31,1 \%(n=33)$ living in other neighbourhoods. A large proportion of the group had worked as a hairdresser for over 16 years, 78,5\% $(n=83$,$) . The most of hairdressers were full time workers, 88,7\%$ $(n=94)$ with 70 of these workers informing that they worked more than 40 hours per week. Moreover, 22,6\% $(n=24)$ reported that they rarely had sufficient time for a meal break when working, and a supplementary $8,5 \%(n=9)$ reported never or rarely having time for a toilet break at work. The majority of hairdressers, however, continue to work with chemically based dyes, 97,2\% $(n=103)$. Concern about the effect of chemical exposure has impelled some hairdressers to use organic based products. In this study, a small proportion of hairdressers reported using organic dyes exclusively in the workplace, $2,8 \%(n=3)$.

\section{Work Ability Index}

The average WAI score among workers was 40,7 points $(\mathrm{SD}=7.2)$, ranging from 24 to 49 points and the prevalence of good capacity for work was 77,36\% (Table 1).

Table 1.

Distribution of the hairdressers according to the Work Ability Index (WAI). Rio de Janeiro, RJ, Brazil, 2013-2014.

$\begin{array}{lccc}\text { Work Ability Index Classification } & \text { Scores } & \mathbf{n} & \% \\ \text { Low } & 07-27 & 14 & 13,21 \\ \text { Moderate } & 28-36 & 10 & 9,43 \\ \text { Good } & 37-43 & 42 & 39,62 \\ \text { Excellent } & 44-49 & 40 & 37,74 \\ \text { Total } & & 106 & 100\end{array}$

It was possible to verify the highest prevalence of good capacity for work were among the hairdressers aged between 41 and 50 years old. Regarding the habits and lifestyles, it was found higher prevalence of good work ability in individuals who rated their general and oral health as good, and in those without signs and of depression symptoms. Still showed good ability those hairdressers who were classified as active or very active in physical activity, into abstinence or alcohol consumption without risk, do not smoke, with social support from one or more relatives and friends, and participating in group activities such as meetings, volunteer work and religion activities. With regard to job characteristics, the good work ability was more prevalent among hairdressers who had only a job, work up to 40 hours per week, did not work at night, had high social support at work and had their jobs classified as low demand, resulting from the combination low demand and high control (Table 2).

In regarding to the perception of the main to the work demands,
Table 2.

Analysis of associations between work ability and demographic and occupational characteristics among hairdressers. Rio de Janeiro, RJ, Brazil, 2013-2014.

\begin{tabular}{|c|c|c|c|c|c|c|c|}
\hline \multirow{3}{*}{$\begin{array}{l}\text { Variables } \\
\text { (categories) }\end{array}$} & \multicolumn{4}{|c|}{ Work ability } & & & \multirow{3}{*}{$\mathrm{p}$-value } \\
\hline & \multicolumn{2}{|c|}{ satisfactory } & \multicolumn{2}{|c|}{ unsatisfactory } & \multicolumn{2}{|c|}{ Total } & \\
\hline & $\mathrm{N}$ & $\%$ & $\mathrm{~N}$ & $\%$ & $\mathrm{~N}$ & $\%$ & \\
\hline \multicolumn{8}{|l|}{ Age (years) } \\
\hline$<30$ & 28 & 80 & 7 & 20 & 35 & 100 & 0,084 \\
\hline $31-50$ & 41 & 78,84 & 11 & 21,16 & 52 & 100 & \\
\hline$>50$ & 16 & 84,21 & 3 & 15,79 & 19 & 100 & \\
\hline \multicolumn{8}{|c|}{ Income (no of minimum wages*) } \\
\hline $1-2$ & 37 & 86,05 & 6 & 13,95 & 43 & 100 & 0,021 \\
\hline $3-5$ & 46 & 85,18 & 8 & 8,42 & 54 & 100 & \\
\hline$>6$ & 9 & 100 & 0 & 0 & 9 & 100 & \\
\hline \multicolumn{8}{|l|}{ Schooling } \\
\hline Primary school & 72 & 88,88 & 9 & 11,12 & 81 & 100 & 0,043 \\
\hline Secondary school & 21 & 84 & 4 & 16 & 25 & 100 & \\
\hline \multicolumn{8}{|l|}{ Marital status } \\
\hline Single & 20 & 90,91 & 2 & 9,09 & 22 & 100 & 0,002 \\
\hline Married & 63 & 86,3 & 10 & 13,7 & 73 & 100 & \\
\hline Not married & 6 & 85,7 & 1 & 14,3 & 7 & 100 & \\
\hline Widowed & 4 & 100 & 0 & 0 & 4 & 100 & \\
\hline \multicolumn{8}{|l|}{ Years in job } \\
\hline$<3$ & 28 & 96,55 & 1 & 3,45 & 29 & 100 & 0,034 \\
\hline $3-10$ & 57 & 83,82 & 11 & 16,18 & 68 & 100 & \\
\hline$>11$ & 7 & 77,77 & 2 & 22,23 & 9 & 100 & \\
\hline \multicolumn{8}{|l|}{ Job satisfaction } \\
\hline Satisfied & 54 & 88,52 & 7 & 11,48 & 61 & 100 & 0,092 \\
\hline Intermediate & 26 & 86,66 & 4 & 13,34 & 30 & 100 & \\
\hline Dissatisfied & 11 & 73,33 & 4 & 26,67 & 15 & 100 & \\
\hline
\end{tabular}

* Minimum wage in Brazilian Reals (R\$).

$59,43 \% \quad(n=63)$ perceived their work determinants as both, physical and mental, 29,25\% $(\mathrm{n}=31)$ as physical, and $11,32 \%$ $(n=12)$ as mental demands.

In regarding of the CoPsoQ Questionnaire, related to the psychological factors (health), it were made measures in variables: General health - evaluation of health conditions as a whole; Vitality - available energy levels and fatigue; Psychological welfare - psychological distress; General stress - conduct of escape from difficulties, struggle or contest (behavioral); physical or psychosomatic symptoms (somatic); nervousness and irritability (cognitive); Sleep disorders are serious plenty to affect with emotional functioning, and normal social, physical, mental; and Social support for colleagues - represents nature and type of social support. The responses were grouped according to these steps. In Table 3 are demonstrated associations between work ability and dimensions of health among hairdressers. Mean values for all dimensions of health were significantly upper with satisfactory (good) work ability.

Table 3.

Analysis of associations between work ability and dimensions of health among hairdressers. Rio de Janeiro, RJ, Brazil, 2013-2014.

\begin{tabular}{llllll} 
Dimension of health & \multicolumn{2}{c}{$\begin{array}{c}\text { Work ability } \\
\text { satisfactory }\end{array}$} & \multicolumn{2}{c}{ unsatisfactory } & p-value \\
& \multicolumn{2}{c}{$\begin{array}{c}\text { Mean (SE) } \\
\text { Gean (SE) }\end{array}$} \\
General health & 77,72 & 1,62 & 61,12 & 3,07 & 0,008 \\
Vitality & 79,43 & 2,77 & 53,98 & 5,79 & 0,092 \\
Psychological welfare & 79,11 & 2,56 & 59,87 & 5,29 & 0,017 \\
Behavioral stress & 85,21 & 1,55 & 72,42 & 2,76 & 0,099 \\
Psychosomatic stress & 73,09 & 2,05 & 45,07 & 4,18 & 0,005 \\
Cognitive stress & 78,12 & 1,98 & 50,68 & 3,89 & 0,009 \\
Sleep disorders & 62,56 & 1,82 & 42,22 & 3,54 & 0,048 \\
Social support for colleagues & 69,26 & 1,68 & 52,15 & 3,28 & 0,104
\end{tabular}


Complementing, most participants indicated good general health $(77,36)$ and vitality $(50,94 \%)$. Not expressive, but the anxiety symptoms had higher frequency than depressive $(14,15 \%$ and $12,26 \%$, respectively). The symptoms of stress were: difficulty to think clearly $(16,03 \%)$, pain or problems in the stomach $(13,21 \%)$, tension in various muscles $(15,1 \%)$, difficulty making decisions $(13,21 \%)$, lack of initiative $(8,49 \%)$ and tightness or chest pain $(9,43 \%)$.

Despite not be a significant number, also was evident that some respondents' hairdressers presented some vulnerability to anxiety symptoms, depression, psychological well-being (16,98\%); and stress-related $(17,92 \%)$; especially symptoms of anxiety and depression, psychological well-being (4,72\%), and general stress (7,55\%).

\section{DISCUSSION}

The consistency of the questionnaires applied was satisfactory (Cronbach's alpha $\geq 0,70$ ). Mean level of satisfaction amongst workers was comparatively high. Nevertheless, it is well recognised that only a small number of workers actually express their frustration, which may have as a consequence to an underestimated predominance of dissatisfaction in work. Great levels of satisfaction are perceived even in the harshest circumstances, including inadequate working conditions, high rates of absenteeism, marked division of labor, and accidents. ${ }^{29}$

Working conditions in the industrial countries have experienced numerous, partly fundamental changes over the last decades. Alongside with comprehensive changes of production conditions and realities in industry, administration and service, demands on the employees are also changing. Time and local flexibility, high toughness or social competences are becoming more and more key qualifications. Consequently, sick-leave days and treatment costs due to psychosocial factors have increased systematically. Labor relations, historically vulnerable in Brazil, cause to workers the constant imminent risk of unemployment. Which represents, objectively, the possibility of social exclusion or inclusion in the informal market, resulting in less access to social benefits, especially the health. ${ }^{3,29,30}$ In addition, older professionals had higher job insecurity and higher prevalence of psychological symptoms. Age has proved to be an important factor in relations between these variables in studies. ${ }^{4,31}$ Moreover, the contemporary labor market tends to exclude older people. ${ }^{32}$

In the population studied, all dimensions of mental health assessed were linked with work ability. Mental health is commonly recognised as less fully associated to work ability than physical health ${ }^{4,33}$, and is observed as more applicable for professions with mainly mental necessities. ${ }^{8,34-36}$

\section{CONCLUSION}

In conclusion, the results revealed that better physical and mental health are associated with greater work ability representing that, the better the worker's health, the greater his work ability. The administrators of beauty salons should be aware of the results obtained with this category of workers so little studied, but very prominent today, to pore in creating an environment conducive to maintaining the work capacity and well-being of hairdressers, mitigating the problems encountered with this study. This provides indication of the prominence of taking in account health in all its dimensions. 
REFERENCIAS

1. Peiró JM. Desencadenantes del estrés laboral. Madrid: Eudema; 1993.

2. Dejours C. Introduction: psychodynamique du travail. Rev Int Psychol. 1996;5:5-12.

3. Minayo-Gomez C, Lacaz FAC. Saúde do Trabalhador: novas-velhas questões. Ciênc Saúde Coletiva. 2005;10(4):797-807.

4. Hotopp U. The ageing workforce: a health issue? Econ Labour Market Rev. 2007;1(2):30-35.

5. Porto $L$ et al. Associação entre distúrbios psíquicos e aspectos psicossociais do trabalho de professores. Rev Saude Publica. 2006;40(5):818-826.

6. Dejours C. Subjetividade, trabalho e ação. Rev Prod. 2004;14(3):27-34.

7. Jacques MG, Codo W. Saúde Mental \&t Trabalho: Leituras. Petrópolis: Vozes; 2002.

8. De Vries MW, Wilkerson B. Stress, work and mental health: a global perspective. Acta Neuropsychiatr. 2003;15(1):44-53.

9. Tuomi $K$, Ilmarinen J, Jahkola A, Katajarinne L, Tulkki A. Índice de capacidade para o trabalho. São Carlos: Edufscar; 2005.

10. Sabin-Farrell R, Turpin G. Vicarious traumatization: implications for the mental health of health workers? Clin Psychol Rev. 2003;23(3):449-480.

11. Caraballo-Arias $Y$, Rodríguez $A R$, Rivero $A$, Rangel $R G$, Covaro MB. Riesgos Laborales en Trabajadores de Barberias y Peluquerias de Economía Informal. Caracas, Venezuela. Cienc Trab. 2013;46:18-23,

12. Martikainen P, Bartley M., Lahelma E. Psychosocial determinants of health in social epidemiology. Int J Epidemiol. 2002;31(1):1091-1093.

13. Camelo $S$, Angerami E. Riscos psicossociais no trabalho que podem levar ao estresse: Uma análise da literatura. Ciência, Cuidado \& Saúde. 2008;7(2):232-240.

14. Verbeek J, Morata TC, Ruotsalainen J, Vainio H. Prevention of occupational diseases: implementing the evidence. Cochr Datab Syst Rev. 2013, 30 April;4:ED000056. dx.doi.org/10.1002/14651858.ED000056

15. Araújo TM, Graça $C$, Araújo E. Estresse ocupacional e saúde: contribuições do Modelo Demanda-Controle. CiêncSaúde Coletiva. 2003;8(4):991-1003.

16. Murta S, Tróccoli B. Avaliação de Intervenção em Estresse Ocupacional. Psic: Teor e Pesq. 2004;20(1):39-47.

17. Cox T, Griffiths A, Rial-González E. Research on work-related stress. Luxembourg: Office for Official Publications of the European Communities; 2000.

18. Harrach A. Arbeitswissenschaftliche Psychosomatik - arbeitsbedingtepsychische und psychosomatische Störungen. In: Teske $U$, Witte $B$, editors. Präventionarbeitsbedingter Erkrankungen. Band 2: Gesundheitliche Auswirkungen und Erkrankungsschwerpunkte. Hamburg: VSA; 2000.

19. Richter G. Psychische Belastung und Beanspruchung. Stress, psychische Ermüdung, Monotonie, psychische Sättigung. Bremerhaven: Wirtschaftsverlag NW; 2000.

20. IImarinen J, Tuomi K. Promoting excellent work ability and preventing poor work ability: the same determinants? Results from the Swedish HAKuL study. Occup Environ Med. 2006;63:113-120.
21. Alavinia SM, De Boer AG, Van Duivenbooden JC, Frings-Dresen MH, Burdorf A. Determinants of work ability and its predictive value for disability among Dutch construction workers. Occup Med. 2008;59:32-37.

22. Kristensen TS, Hannerz H, Høgh A, Borg V. The Copenhagen Psychosocial Questionnaire (COPSOQ) - a tool for the assessment and improvement of the psychosocial work environment. Scand J Work Environ Health. 2005;31:438-449.

23. IBGE. Instituto Brasileiro de Geografia e Estatística. IBGE Cidades@ [on line]. Brasilia: IBGE; 2010 [cited Jan 2015]. Available on: http://www.cidades.ibge. gov.br/xtras/home.php

24. García-Rodríguez A, Gutiérrez-Bedmar $M$, Bellón-Saameño JA, MuñozBravo C, Fernández-Crehuet Navajas J. Psychosocial stress environment and health workers in public health: Differences between primary and hospital care. Aten Primaria.2014; pii: S0212-6567(14)00287-X.

25. Rabe M, Giacomuzzi S, Nübling M. Psychosocial workload and stress in the workers' representative. BMC Public Health. 2012;12:909. doi: 10.1186/14712458-12-909.

26. Ilmarinen J, Tuomi K, Seitsamo J. New dimensions of work ability. International Congress Series. 2005;1280:3-7.

27. IImarinen J. Work ability: a comprehensive concept for occupational health research and prevention. Scand J Work Environ Health. 2009;35(1):1-5.

28. Goldenhar LM, LaMontagne AD, Katz $T$, Heaney $C$, Landsbergis $P$. The Intervention Research Process in Occupational Safety and Health: An overview from the national occupational research agenda intervention effectiveness research team. J Occup Environ Med. 2001;43(7):616-622.

29. Faragher EB, Cass M, Cooper CL. The relationship between job satisfaction and health: a meta-analysis. Occup Environ Med. 2005;62:105-12.

30. IImarinen J. Aging and work. Occup Environ Med. 2001;58:546-52.

31. Näswall K, Witte HD. Who feels insecure in Europe? Predicting job insecurity from background variables. EconInd Democracy. 2003;24(2):189-215.

32. Strazdins L, D'Souza RM, Lim LL, Broom DH, Rodgers B. Job strain, job insecurity, and health: rethinking the relationship. J Occup Health Psych. 2004;9(4):296-305.

33. Glina $D$, Rocha $L$, Batista $M$, Mendonça $M$. Saúde mental e trabalho: uma reflexão sobre o nexo com o trabalho e o diagnóstico com base na prática. Cad Saúde Pública. 2001;17(3):607-616

34. Martins MCA. Factores de risco psicossociais para a saúde mental. Rev Millenium. 2004;255-268.

35. Tabanelli $\mathrm{M}$ et al. Available instruments for measurement of psychosocial factors in the work environment. IntArchOccEnvHea. 2008;82(1):1-12.

36. Ribeiro JP, Marques T. A avaliação do estresse: a propósito de um estudo de adaptação da escala de percepção de estresse. Psic Saúde \& Doencas. 2009;10(2):237-248. 